\title{
Evaluation of Testing Facilities for a High Temperature Fission Chamber Design
}

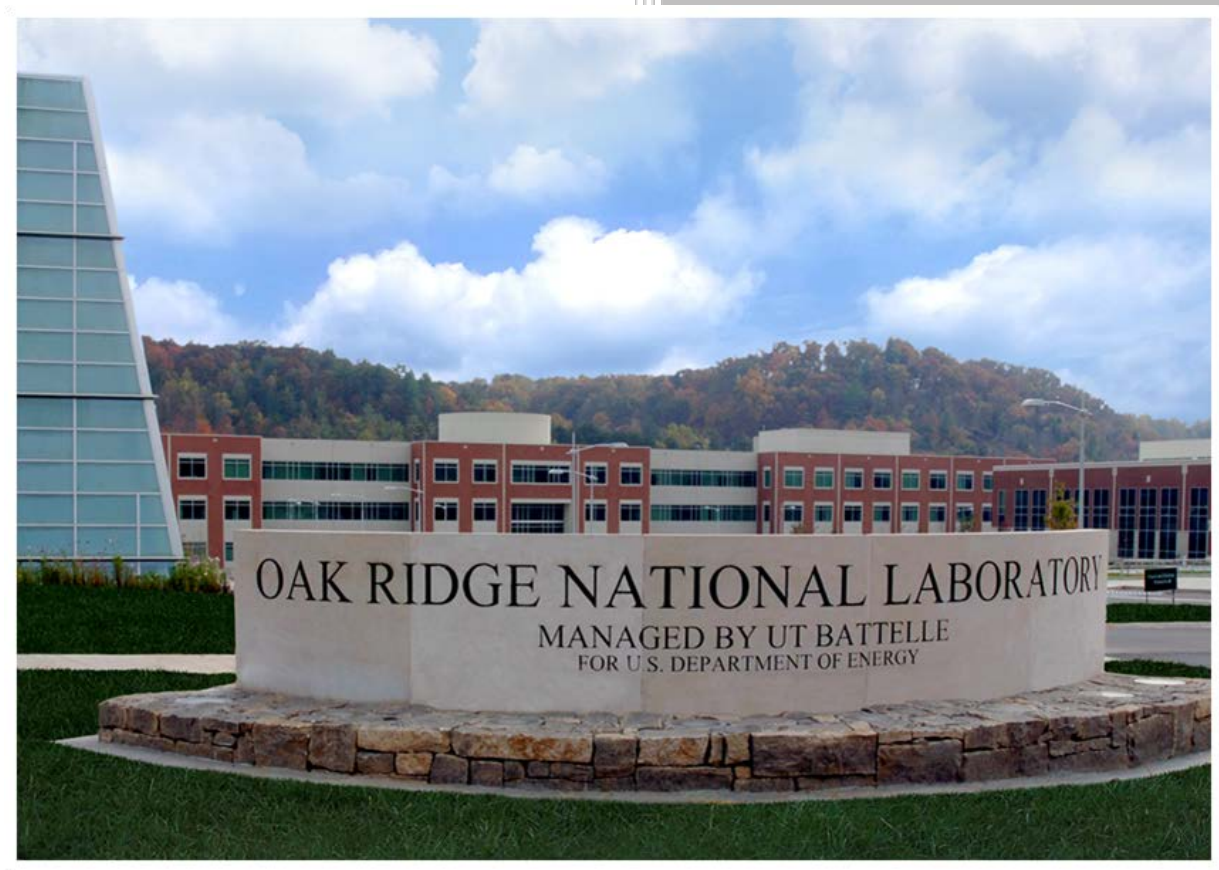

Approved for public release. Distribution is unlimited.

N. Dianne Bull Ezell Nesrin Ozgan Cetiner

May 2018 


\title{
DOCUMENT AVAILABILITY
}

Reports produced after January 1, 1996, are generally available free via US Department of Energy (DOE) SciTech Connect.

\section{Website http://www.osti.gov/scitech/}

Reports produced before January 1, 1996, may be purchased by members of the public from the following source:

\author{
National Technical Information Service \\ 5285 Port Royal Road \\ Springfield, VA 22161 \\ Telephone 703-605-6000 (1-800-553-6847) \\ TDD 703-487-4639 \\ Fax 703-605-6900 \\ E-mail info@ntis.gov \\ Website http://classic.ntis.gov/
}

Reports are available to DOE employees, DOE contractors, Energy Technology Data Exchange representatives, and International Nuclear Information System representatives from the following source:

Office of Scientific and Technical Information

PO Box 62

Oak Ridge, TN 37831

Telephone 865-576-8401

Fax 865-576-5728

E-mail reports@osti.gov

Website http://www.osti.gov/contact.html

This report was prepared as an account of work sponsored by an agency of the United States Government. Neither the United States Government nor any agency thereof, nor any of their employees, makes any warranty, express or implied, or assumes any legal liability or responsibility for the accuracy, completeness, or usefulness of any information, apparatus, product, or process disclosed, or represents that its use would not infringe privately owned rights. Reference herein to any specific commercial product, process, or service by trade name, trademark, manufacturer, or otherwise, does not necessarily constitute or imply its endorsement, recommendation, or favoring by the United States Government or any agency thereof. The views and opinions of authors expressed herein do not necessarily state or reflect those of the United States Government or any agency thereof. 
Electrical and Electronics System Research Division

\section{Evaluation of Testing Facilities for a High-Temperature Fission Chamber Design}

N. Dianne Bull Ezell

Nesrin Ozgan Cetiner

Date Published: May 2018

Prepared by

OAK RIDGE NATIONAL LABORATORY

Oak Ridge, TN 37831-6283

managed by

UT-BATTELLE, LLC

for the

US DEPARTMENT OF ENERGY

under contract DE-AC05-00OR22725 



\section{CONTENTS}

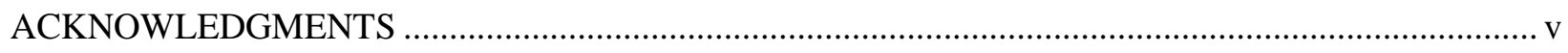

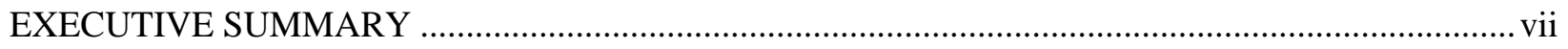

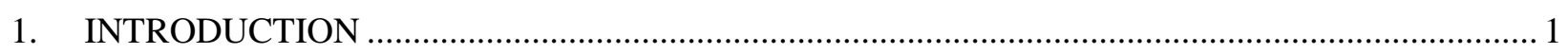

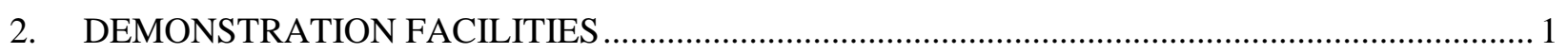

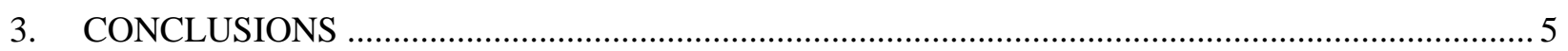

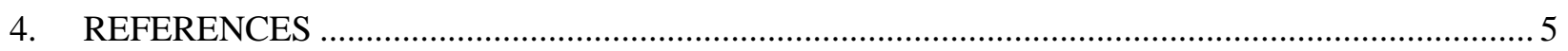





\section{ACKNOWLEDGMENTS}

This work is funded by the US Department of Energy Office of Nuclear Energy under the Advanced Reactor program. The author would like to thank the operating staff of the facilities discussed in this document for providing information about their research reactors and facilities. 



\section{EXECUTIVE SUMMARY}

Oak Ridge National Laboratory (ORNL) developed a first-of-its-kind high-temperature fission chamber (HTFC) prototype that could survive in the harsher environments of advanced reactors with high flux fields up to $10^{13} \mathrm{n} / \mathrm{cm}^{2}$-s and temperatures upwards of $700^{\circ} \mathrm{C}$. The first prototype of the HTFC was demonstrated at the Ohio State University Research Reactor (OSURR) in October 2017. The experiment at the OSURR was designed to demonstrate four regions of operation: low flux and low temperatures, low flux and high temperatures, high flux and low temperatures, and high flux and high temperatures. Although some problems developed during the experiment at the OSURR, data was obtained and the fission chamber was shipped back to ORNL. The problems were diagnosed and documented at ORNL, and the HTFC was reassembled. Testing will proceed at ORNL at temperatures up to $700^{\circ} \mathrm{C}$. This report discusses other possible test facilities to demonstrate the HTFC instrument prototype after reassembly. 



\section{INTRODUCTION}

Next-generation advanced nuclear reactors will require instrumentation designed to withstand harsher environments than previous reactors. Fission chambers are one instrument used for monitoring power and in-core fuel management. Existing materials and fill gases used in fission chamber designs cannot withstand the higher temperatures and corrosive environments of high-temperature gas-cooled and molten salt reactors. Although none of these advanced reactors currently exists commercially, the instrumentation prototypes need to be tested and qualified. For the fission chamber part of these tests, it is important to select demonstration facilities with the desired flux and that allow for furnaces to be heated to elevated temperatures.

\section{DEMONSTRATION FACILITIES}

The high-temperature fission chamber (HTFC) prototype was designed to meet the following conditions: (1) sensitivity of $1 \mathrm{nv}$ (or $\mathrm{n} / \mathrm{cm}^{2} / \mathrm{s}$ ); (2) harsh environments like FLiBe (molten salt) at $1 \mathrm{~atm}$ or helium (gas-cooled) at $79 \mathrm{~atm}$; (3) temperatures from $700^{\circ} \mathrm{C}$ (FLiBe cooled) to $800^{\circ} \mathrm{C}$ (helium cooled); (4) thermal neutron flux equivalent to $10^{13} \mathrm{nv}$; and (5) a lifetime expectancy of approximately 2 years. Although some of these conditions are easily met in conventional reactors, some conditions must be implemented through other means. For example, to reach 700 to $800^{\circ} \mathrm{C}$, a furnace must be installed with the fission chamber. Many facilities were asked to complete a table of specifications about their facilities (see Table 1). Several inquiries were made to help identify the best demonstration facility for the experiment specifications

Table 1. Description of facility capabilities

\begin{tabular}{|c|c|}
\hline Specification & Description \\
\hline Management & Facility operator \\
\hline City & Facility location \\
\hline Reactor Type & Type or reactor or other facilities on site \\
\hline Maximum thermal flux $\left(\mathrm{x} 10^{14} \mathrm{n} / \mathrm{cm}^{2} \cdot \mathrm{s}\right)$ & Maximum thermal neutron flux \\
\hline Maximum fast flux $\left(\mathrm{x} 10^{14} \mathrm{n} / \mathrm{cm}^{2} \cdot \mathrm{s}\right)$ & Maximum fast neutron flux \\
\hline Coolant inlet temperature $\left({ }^{\circ} \mathrm{C}\right)$ & $\begin{array}{l}\text { Coolant temperature is the temperature (heat sink) where experiments } \\
\text { will be exposed to on their outer boundary }\end{array}$ \\
\hline Operating pressure (MPa) & $\begin{array}{l}\text { How much pressure the experiment will be exposed to if there is any } \\
\text { pressure boundary }\end{array}$ \\
\hline Experiment facility diameter (mm) & $\begin{array}{l}\text { The experiment location, your upper limit for the outer dimension of } \\
\text { your experiment }\end{array}$ \\
\hline Experiment active length (mm) & Your boundary length for the experiment \\
\hline Experiment cabling/rack installation & $\begin{array}{l}\text { How do users need to design experiment electronics for installation at the } \\
\text { facility? }\end{array}$ \\
\hline Typical operating fraction & $\begin{array}{l}\text { Is the reactor operating on demand or continuously? That schedule may } \\
\text { affect your irradiation time/removal }\end{array}$ \\
\hline Existing flow loops & Are there built in flow loops? Is there restriction put in one? \\
\hline Existing salt facility & Are there built in salt loops? Is there restriction to put one? \\
\hline Hot cell capability & Are there hotcells within the facility? \\
\hline Activity restrictions & $\begin{array}{l}\text { What is the activity restriction, safety margin? Worst case scenario } \\
\text { margin. }\end{array}$ \\
\hline High temperature restrictions & $\begin{array}{l}\text { Are heaters allowed? Do they already have heaters? What is the } \\
\text { temperature limit on heated experiments? }\end{array}$ \\
\hline Web link & Website or contact information \\
\hline
\end{tabular}


Although several facilities were contacted as potential demonstration locations, only a few were able to meet the needs of the experiment. The few things considered important for this experiment are

- reactor type and instrumentation feedthrough/instrumentation installation,

- reactor power range and availability to change power, and

- availability to install furnaces with the instrument.

The information received from the facilities is shown in Table 2. The reactor facilities are ordered alphabetically in the table. The information in these tables was provided by the individuals running the facilities. The websites in the tables are for contact information only because most of the information is not available on the websites or in the user manuals. For the future, it is recommended that these facilities be contacted individually for updated information. 
Table 2. Contacted reactor facilities and their capabilities

\begin{tabular}{|c|c|c|c|c|}
\hline Specification & Advanced Test Reactor (ATR) ${ }^{1}$ & $\begin{array}{l}\text { High Flux Isotope } \\
\text { Reactor (HFIR) }\end{array}$ & HTTR (Japan) ${ }^{3}$ & MIT Reactor (MITR) ${ }^{4}$ \\
\hline Management & Idaho National Laboratory & $\begin{array}{l}\text { Oak Ridge National } \\
\text { Laboratory }\end{array}$ & $\begin{array}{l}\text { Japan Atomic Energy } \\
\text { Agency }\end{array}$ & Massachusetts Institute of Technology \\
\hline City, State & Idaho Falls, ID & Oak Ridge, TN & Oarai-machi, Japan & Cambridge, MA \\
\hline Reactor type & Light water & Light water & $\begin{array}{l}\text { High-temperature gas } \\
\text { cooled }\end{array}$ & Heavy water reflected \\
\hline $\begin{array}{l}\text { Maximum thermal flux }\left(\mathrm{x}^{10^{14}}\right. \\
\left.\mathrm{n} / \mathrm{cm}^{2} \cdot \mathrm{s}\right)\end{array}$ & $\begin{array}{lc}\text { NE/NW flux trap } & 4.4 \\
\text { Other flux traps } & 4.4 \\
\text { A-1 to A-8 } & 1.9 \\
\text { A-9 to A-12 } & 2.0 \\
\text { B-1 to B- } 8 & 2.5 \\
\text { B-9 to B-12 } & 1.1 \\
\text { H positions } & 1.9 \\
\text { Large I } & 0.17 \\
\text { Medium I } & 0.34 \\
\text { Small I } & 0.84\end{array}$ & 21 & $\begin{array}{l}\text { Standpipe hole } 0.7(<2.38 \\
\mathrm{eV}) \\
\text { Basket in fuel block region } \\
0.5\end{array}$ & 0.6 \\
\hline $\begin{array}{l}\text { Maximum fast flux }\left(\mathrm{x}^{10^{14}}\right. \\
\left.\mathrm{n} / \mathrm{cm}^{2 \cdot} \cdot \mathrm{s}\right)\end{array}$ & $\begin{array}{ll}\text { NE/NW flux trap } & 2.2(>1 \mathrm{MeV}) \\
\text { Other flux traps } & 0.97 \\
\text { A-1 to A-8 } & 1.7 \\
\text { A-9 to A-12 } & 2.3 \\
\text { B-1 to B- } 8 & 2.3 \\
\text { B-9 to B-12 } & 0.81 \\
\text { H positions } & 1.7 \\
\text { Large I } & 0.013 \\
\text { Medium I } & 0.013 \\
\text { Small I } & 0.032 \\
\end{array}$ & 11 & $\begin{array}{l}\text { Standpipe hole } 0.2(>0.18 \\
\text { MeV) } \\
\text { Basket in fuel block region } \\
0.2\end{array}$ & 1.2 \\
\hline Coolant inlet temperature $\left({ }^{\circ} \mathrm{C}\right)$ & 52 & 50 & 395 & 42 \\
\hline Operating pressure (MPa) & 2.5 & & 4 & 0.1 \\
\hline $\begin{array}{l}\text { Experiment facility diameter } \\
(\mathrm{mm})\end{array}$ & $\begin{array}{lc}\text { NE/NW flux trap } & 133 \\
\text { Other flux traps } & 76 \\
\text { A-1 to A-8 } & 40 \\
\text { A-9 to A-12 } & 16 \\
\text { B-1 to B-18 } & 22 \\
\text { B-9 to B-12 } & 38 \\
\text { H positions } & 16 \\
\text { Large I } & 127 \\
\text { Medium I } & 89 \\
\text { Small I } & 38 \\
\end{array}$ & 16-69 & $\begin{array}{l}\text { I-type test train used in the } \\
\text { past for material testing fits } \\
\text { into a standpipe hole of } 200 \\
\text { mm diameter. } \\
\text { Graphite basket can replace } \\
\text { a fuel block in the core and } \\
\text { has a hole diameter of } \\
\text { about } 300 \mathrm{~mm} \text {. }\end{array}$ & 50.8 \\
\hline $\begin{array}{l}\text { Experiment active length } \\
(\mathrm{mm})\end{array}$ & 1220 & 508 & $\begin{array}{l}\text { I-type test train specimen } \\
\text { region has a length of } 100 \\
\mathrm{~mm} \text {, but the hole in which } \\
\text { the train is inserted runs the } \\
\text { length of the core. (about } \\
2,900 \mathrm{~mm} \text { ). } \\
\text { The graphite basket has a } \\
\text { length of } 580 \mathrm{~mm}\end{array}$ & 560 \\
\hline $\begin{array}{l}\text { Experiment cabling/wrack } \\
\text { installation }\end{array}$ & $\begin{array}{l}\text { Instrument leads exit through the top of a } \\
\text { capsule. Cables run out of the vessel and } \\
\text { into experiment cubicles below the reactor } \\
\text { enclosure }\end{array}$ & & $\begin{array}{l}\text { Unknown. We would have } \\
\text { to discuss reactor tech specs } \\
\text { with JAEA. }\end{array}$ & $\begin{array}{l}\text { MIT-NRL will work with users on } \\
\text { electronics and cabling for lead-out } \\
\text { experiments. }\end{array}$ \\
\hline Typical operating fraction & $75 \%$ & 0.46 & $\begin{array}{l}\text { Currently shutdown; } \\
\text { awaiting restart } \\
\text { authorization from } \\
\text { regulatory. Restart } \\
\text { anticipated in } 2019 . \\
\end{array}$ & $\begin{array}{l}\text { 60\%; operating 24/7; each cycle lasts } \\
\text { 8-10 weeks. Can reduce cycle length } \\
\text { as necessary. }\end{array}$ \\
\hline Fuel restrictions & $\begin{array}{l}\text { Nothing is explicitly forbidden. All items } \\
\text { introduced into the core are subject to } \\
\text { analysis of reactivity and thermo- } \\
\text { mechanical performance to determine } \\
\text { whether safety limits are challenged. }\end{array}$ & & $\begin{array}{l}\text { Likely. We would have to } \\
\text { discuss with JAEA. }\end{array}$ & $<100 \mathrm{~g} \mathrm{U}^{235}$ \\
\hline Existing flow loops & $\begin{array}{l}\text { Independent flow loops (InPile Tubes) are } \\
\text { installed in } 6 \text { of the } 9 \text { flux traps. }\end{array}$ & Unknown & No & $\begin{array}{l}1 \text { pressurized water loop. New loop } \\
\text { can be designed and built to meet } \\
\text { experiment specifications. }\end{array}$ \\
\hline Existing salt facility & No, other than the usual tech spec limits. & Unknown & No & Yes \\
\hline Hot cell capability & $\begin{array}{l}\text { Yes, but most PIE is performed in the } \\
\text { HFEF or FCF hot cells at the Materials and } \\
\text { Fuels Complex down the road. }\end{array}$ & Unknown & On the Oarai site, probably. & $\begin{array}{l}2 \text { full hot cells and } 1 \text { hot box with } \\
\text { manipulators in reactor containment } \\
\text { building. }\end{array}$ \\
\hline Activity restrictions & See the ATR Users Guide. & Unknown & $\begin{array}{l}\text { Unknown. We would have } \\
\text { to discuss reactor tech specs } \\
\text { with JAEA. }\end{array}$ & $\begin{array}{l}\text { Activity restrictions are primarily } \\
\text { determined for postirradiation } \\
\text { handling. This is unlikely to be an } \\
\text { issue for fission chambers/detectors. }\end{array}$ \\
\hline High-temperature restrictions & $\begin{array}{l}\text { Conditions in the loop experiments are } \\
\text { independent of the primary coolant } \\
\text { conditions that are specified during the } \\
\text { experiment design phase (negotiations } \\
\text { between User Requirements and ATR } \\
\text { Engineering). For drop-in capsules } \\
\text { (locations not in the loops), heating is by } \\
\text { irradiation only; temperatures are } \\
\text { controlled via capsule design (and } \\
\text { regulation of insulating gas composition). }\end{array}$ & Unknown & $\begin{array}{l}\text { The HTTR operates in the } \\
\text { range suitable for testing } \\
\text { this instrument. }\end{array}$ & $\begin{array}{l}\text { Heaters are allowed for in-core and } \\
\text { beam port irradiation facilities. The } \\
\text { heater can be designed to meet } \\
\text { experiment requirements. }\end{array}$ \\
\hline Web link & $\begin{array}{l}\text { https://nsuf.inl.gov/Home/PartnerFacility/6 } \\
52\end{array}$ & $\begin{array}{l}\text { https://neutrons.ornl } \\
\text {.gov/hfir }\end{array}$ & $\begin{array}{l}\text { https://httr.jaea.go.jp/eng/in } \\
\text { dex.html }\end{array}$ & https://nrl.mit.edu/ \\
\hline Point of contact & Hans Gougar & Don Raby & Hiroyuki Sato & Lin-Wen $\mathrm{Hu}$ \\
\hline
\end{tabular}


Table 3. List of reactor facility and their capabilities (continued)

\begin{tabular}{|c|c|c|c|c|}
\hline Specification & $\begin{array}{c}\text { University of Missouri } \\
\text { Research Reactor } \\
\text { (MURR) }^{5}\end{array}$ & $\begin{array}{c}\text { The Ohio State University } \\
\text { Research Reactor } \\
\text { (OSURR) }^{6}\end{array}$ & $\begin{array}{l}\text { Penn. State Breazeale Nuclear } \\
\text { Reactor (RSIC) }\end{array}$ & VFTR \\
\hline Management & University of Missouri & The Ohio State University & Penn. State University & \\
\hline City, State & Columbia, MO & Columbus, $\mathrm{OH}$ & University Park, PA & \\
\hline Reactor type & Tank & Pool & TRIGA & \\
\hline $\begin{array}{l}\text { Maximum thermal flux }\left(\mathrm{x}^{10^{14}}\right. \\
\left.\mathrm{n} / \mathrm{cm}^{2} \cdot \mathrm{s}\right)\end{array}$ & 4 & 0.1 & Up to 0.33 (central thimble) & \\
\hline $\begin{array}{l}\text { Maximum fast flux }\left(\mathrm{x}^{10^{14}}\right. \\
\left.\mathrm{n} / \mathrm{cm}^{2} \cdot \mathrm{s}\right)\end{array}$ & 0.7 & 0.07 & Up to 0.16 (central thimble) & \\
\hline Coolant inlet temperature $\left({ }^{\circ} \mathrm{C}\right)$ & 50 & n/a (dry facility) & $25-35$ & \\
\hline Operating pressure (MPa) & $\begin{array}{l}0.176 \text { Mpa ( } 25.5 \text { psi at } 25 \\
\text { feet underwater) }\end{array}$ & 0.1 & $\begin{array}{l}\text { No pressure boundary; open pool } \\
\text { reactor }\end{array}$ & \\
\hline $\begin{array}{l}\text { Experiment facility diameter } \\
\text { (mm) }\end{array}$ & $\begin{array}{l}\text { Depends on the } \\
\text { experiment (willing to } \\
\text { customize for collaborator } \\
\text { needs) }\end{array}$ & $\begin{array}{l}10 \text { in. dry tube; } 7 \text { in. dry } \\
\text { tube, } 2.4 \text { in. dry tubes (2), } \\
1.3 \text { in. dry tube }\end{array}$ & $\begin{array}{l}\text { Central thimble: } 32 \mathrm{~mm} \text {; other } \\
\text { facilities are available up to } 100 \\
\text { mm, with lower flux limits. }\end{array}$ & \\
\hline $\begin{array}{l}\text { Experiment active length } \\
\text { (mm) }\end{array}$ & 765 & $2 \mathrm{ft}$ & $\begin{array}{l}\text { N/A, fuel length is } 380 \mathrm{~mm} \\
\text { (experiments }>75 \mathrm{~mm} \text { will have } \\
\text { nonuniform axial flux). }\end{array}$ & \\
\hline $\begin{array}{l}\text { Experiment cabling/wrack } \\
\text { installation }\end{array}$ & $\begin{array}{l}\text { Depends on the type, size, } \\
\text { and space availability }\end{array}$ & $\begin{array}{l}30-35 \mathrm{ft} \text { of cabling to stand- } \\
\text { alone equipment (e.g., we } \\
\text { just installed at the top of } \\
\text { the storage pool and did not } \\
\text { have to conform to racks) }\end{array}$ & $\begin{array}{l}\text { Experiments need to be reviewed for } \\
\text { safety. Electronics must not interfere } \\
\text { with reactor control system }\end{array}$ & \\
\hline Typical operating fraction & $\begin{array}{l}\text { Operates at } 10 \text { MW } 24 \\
\text { hours per day and } 6.5 \text { days } \\
\text { per week }\end{array}$ & On demand, first shift only & $\begin{array}{l}\text { Reactor ops are on demand, } \\
\text { typically } 4-6 \text { hours/day }\end{array}$ & \\
\hline Fuel restrictions & $\begin{array}{l}\text { Yes, depending on } \\
\text { experiment }\end{array}$ & $\begin{array}{l}\text { We do have a license limit } \\
\text { for SNM on site. }\end{array}$ & $\begin{array}{l}\text { NU and DU can be irradiated. } \\
\text { Enriched uranium irradiations } \\
\text { require a license amendment }\end{array}$ & \\
\hline Existing flow loops & $\begin{array}{l}\text { No, depending on } \\
\text { experiment }\end{array}$ & $\begin{array}{l}\text { No built-in flow loops. No } \\
\text { restrictions, but approval of } \\
\text { the Reactor Oversight } \\
\text { Committee might be } \\
\text { required. }\end{array}$ & $\begin{array}{l}\text { There are no built-in flow loops, } \\
\text { although one can be installed }\end{array}$ & \\
\hline Existing salt facility & $\begin{array}{l}\text { No, depending on } \\
\text { experiment }\end{array}$ & $\begin{array}{l}\text { No built-in salt loops. No } \\
\text { restrictions, but approval of } \\
\text { the Reactor Oversight } \\
\text { Committee might be } \\
\text { required. }\end{array}$ & $\begin{array}{l}\text { There are no built-in salt loops, } \\
\text { although one can be installed }\end{array}$ & \\
\hline Hot cell capability & Yes & No & Yes & \\
\hline Activity restrictions & $\begin{array}{l}\text { Determined by Safety } \\
\text { Analysis and Health } \\
\text { Physics }\end{array}$ & $\begin{array}{l}\text { No specific limit for what } \\
\text { we activate using the } \\
\text { reactor, but we are limited } \\
\text { in what doses we can safely } \\
\text { handle. }\end{array}$ & See user note below. ${ }^{a}$ & \\
\hline High-temperature restrictions & $\begin{array}{l}\text { No heaters exist. Heaters } \\
\text { and limits would depend } \\
\text { on experiment. }\end{array}$ & $\begin{array}{l}\text { Heaters are allowed, but we } \\
\text { do not have any for use. } \\
\text { The limit would be a } \\
\text { maximum temperature on } \\
\text { the facility tube wall. }\end{array}$ & $\begin{array}{l}\text { There is no specific limit on heated } \\
\text { experiments. However, experiments } \\
\text { must be reviewed to ensure that fuel } \\
\text { temperature limits will not be } \\
\text { exceeded. The maximum heater } \\
\text { power would be heavily dependent } \\
\text { on experiment location relative to } \\
\text { the fuel. }\end{array}$ & \\
\hline Web link & $\begin{array}{l}\text { http://www.murr.missouri. } \\
\text { edu/operations.php }\end{array}$ & https://reactor.osu.edu/ & www.rsec.psu.edu & \\
\hline Point of Contact & Rob Hall & Andrew Kauffman & Jeffery Geotherm & Sacit Centiner \\
\hline
\end{tabular}

\section{${ }^{a}$ User Note 1:}

From user guide:

e. Experiment materials, except fuel materials, which could off-gas, sublime, volatilize, or produce aerosols under (1) normal operating conditions of the experiment and reactor, (2) credible accident conditions in the reactor, or (3) possible accident conditions in the experiment, SHALL be limited in activity such that the airborne concentration of radioactivity averaged over a year SHALL NOT exceed the limit of Appendix B Table 2 of 10 CFR Part 20

When calculating activity limits, the following assumptions will be used:

1) If an experiment fails and releases radioactive gases or aerosols to the reactor bay or atmosphere, $100 \%$ of the gases or aerosols escape.

2) If the effluent from an experimental facility exhausts through a holdup tank which closes automatically on high radiation level, at least $10 \%$ of the gaseous activity or aerosols produced will escape.

3) If the effluent from an experimental facility exhausts through a filter installation designed for greater than $99 \%$ efficiency for 0.3 micron particles, at least $10 \%$ of these vapors can escape.

4) For materials whose boiling point is above $130^{\circ} \mathrm{F}$ and where vapors formed by boiling this material can escape only through an undisturbed column of water above the core, at least $10 \%$ of these vapors can escape.

f. Each fueled experiment SHALL be controlled such that the total inventory of iodine isotopes 131 through 135 in the experiment is no greater than 1.5 curies. In addition, any fueled experiment which would generate an inventory of more than 5 millicuries (mCi) of I-131 through I-135 SHALL be reviewed to ensure that in the case of an accident, the total release of iodine will not exceed that postulated for the MHA (see Safety Analysis Report, Chapter 13). 


\section{CONCLUSIONS}

This document describes possible demonstration facilities for testing of the HTFC. Each facility was contacted to help build a table of facility capabilities. This data is subject to change in the future as the facilities are updated and their capabilities are modified. After review of the tables, only a select few

facilities were identified that will fit the demonstrate needs of the HTFC. Discussion of future testing of the HTFC is under way.

\section{REFERENCES}

1. Idaho National Laboratory. 2018. “Advanced Test Reactor (ATR).” Accessed May 2018. https://nsuf.inl.gov/Home/PartnerFacility/652.

2. Oak Ridge National Laboratory. 2001. “High Flux Isotope Reactor.” Accessed May 2018. https://neutrons.ornl.gov/hfir.

3. JAEA. 1999. “High Temperature Engineering Test Reactor.” Accessed May 2018. https://httr.jaea.go.jp/eng/index.html.

4. Massachusetts Institute of Technology. 2000. “Nuclear Reactor Laboratory.” Accessed May 2018. https://nrl.mit.edu/.

5. University of Missouri Research Reactor Center. 2008-2018. “MURR.” Accessed May 2018. http://www.murr.missouri.edu/.

6. The Ohio State University. 2018. “Nuclear Reactor Laboratory.” Accessed May 2018. https://reactor.osu.edu/.

7. PennState College of Engineering. 1999. "Radiation Science \& Engineering Center.” Accessed May 2018. http://www.rsec.psu.edu/index.aspx. 